\title{
Preliminary Investigations for Landfill Siting in Lafia, Nasarawa State of Central Nigeria
}

\author{
Namo Micah Musa ${ }^{1}{ }^{*}$, Mallo Stephen ${ }^{2}$, Wazoh Hannatu ${ }^{1}$, Ikeadighi Jane ${ }^{1}$, Elaigwu Samuel ${ }^{1}$, \\ Lucas Dan ${ }^{1}$ \\ ${ }^{1}$ Department of Geology, University of Jos, Jos, Nigeria \\ ${ }^{2}$ Department of Mining Engineering, University of Jos, Jos, Nigeria
}

Email address:

namsmicah@gmail.com (N. M. Musa), profsmallo@gmail.com (M. Stephen), hannatuwazoh@gmail.com (W. Hannatu), jubileerom@gmail.com (I. Jane),sammie190k@gmail.com (E. Samuel), lucasdan1122@gmail.com (L. Dan)

${ }^{*}$ Corresponding author

\section{To cite this article:}

Namo Micah Musa, Mallo Stephen, Wazoh Hannatu, Ikeadighi Jane, Elaigwu Samuel, Lucas Dan. Preliminary Investigations for Landfill Siting in Lafia, Nasarawa State of Central Nigeria. International Journal of Sustainable and Green Energy. Vol. 9, No. 4, 2020 , pp. 73-84. doi: $10.11648 /$ j.ijrse.20200904.11

Received: July 30, 2020; Accepted: August 17, 2020; Published: December 31, 2020

\begin{abstract}
Waste management has taken the front purview in recent years due to the evident and attendant effects of indiscriminate disposal of wastes to the environment. This led to the preliminary investigations for the proposed siting of a landfill facility in Lafia and environs of Nasarawa State in Central Nigeria, with the aim of providing valuable information on the suitability for location for the disposal of Municipal Solid Waste (MSW). The combined use of geo-resistivity, geological and hydrogeological investigations were carried out for the study. Ten Vertical Electrical Soundings (VES) of the Schlumberger array was used to investigate the properties of the subsurface lithologies to determine their properties especially, clay, for siting a landfill. Clay, an attenuating material, is significant for siting a landfill facility because it tends to isolate potentially toxic wastes from the environment by slowing down the movement of leachates into groundwater and the environmental. Quantitative interpretation of data of the VES survey using the IPI2win computer software revealed the presence of four to five geologic layers comprising of sandy top soil $(247-1964 \Omega \mathrm{m})$, silty sand $(98-3488 \Omega \mathrm{m})$, clayeyshally/sand $(68-3922 \Omega \mathrm{m})$, saturated clayey sand $(31-3226 \Omega \mathrm{m})$ and loose sand $(478 \Omega \mathrm{m})$. Clay was found to be abundant in the area and found at depths ranging from $30 \mathrm{~m}$ to infinity. Geologically, structures like lineaments abound and were analysed; they show a dominant trend in the NW - SE direction from the Rosette Diagram. Lineaments are useful for studies because they are possible conduits where decomposed wastes in liquid form, such as leachates, get transported to pollute groundwater. Hydrogeological studies surveyed Static Water Levels (SWL) measurement from 51 hand dug wells in the study area. The SWL ranges between $5.8 \mathrm{~m}$ and $37.1 \mathrm{~m}$. The data from the SWL was used to construct the absolute water level map in a 3D form to show the flow direction of the groundwater. The study revealed the presence of impermeable clays at VES 1, 2, 3, 9 and 10. This is significant for selection for landfill due to its pollution-prevention properties of groundwater pollution. The investigations carried out in this study show that Shabu, a town located about $8 \mathrm{~km}$ from Lafia, is likely suitable for siting a landfill facility; because of the abundance of clay at a shallow depth of $30 \mathrm{~m}$ and with limited preponderance of lineaments.
\end{abstract}

Keywords: Clay, Landfill, Leachates, Lineaments, Municipal Solid Waste, Resistivities, Vertical Electrical Sounding, Shabu

\section{Introduction}

\subsection{Background to the Study}

Waste management, especially in a developing country like Nigeria, is a challenge that is ravaging and affecting the environment adversely. Waste in the form of Municipal
Solid Waste (MSW), comes in different forms which comprise of mixed metals, kitchen waste, paper, food scraps, plastics and glass [1]. Urban wastes constitute a wide range of materials such as food fragments, papers, rags, vegetable remains as well as dust and soil swept from streets and buildings [2]. This study was undertaken because waste management is one of the major challenges faced by 
municipality officials, public health officials, civil engineers and engineering geologists in their quest to safeguard the environment. MSW is defined as unavoidable and unwanted materials in solid, liquid and/or gaseous form which may be hazardous or non-hazardous [3]. Reasons for the huge volumes of MSW generation from households today may be related to the growth in the sizes of most Nigerian towns and cities leading to population explosion in leaps and bounds. As a result, households resort to indiscriminate disposal of MSW on streams, roadsides, vacant pieces of land, or borrow pits thereby leading to air pollution, groundwater and soil pollution, within Lafia metropolis of Nasarawa State [4, 5]. MSW has brought about environmental problems such as bad odours of wastes that attract flies, mosquitoes, snakes and rodents thereby serving as vectors, carrying infectious diseases. One of the ways to contain the menace of MSW disposal majorly utilized in the world today is the landfill. The construction and operation of an engineered sanitary landfill ensures proper and adequate waste management by disposing MSW in a way that safeguards the environment by laying the wastes in thin layers and subsequently compressing them into smaller volumes possibly by covering them with compacted soil after each working day. A number of developed countries have adequately managed and curbed their wastes as a result of proper planning and effective waste management policies [6]. Landfills in years to come will become the major mode of waste disposal because cheap equipment and machines are required to operate them.

Site selection suitable for landfills however, has become one of the greatest problems because several factors are taken into consideration such as the geology, proximity to residential houses, river/stream channels, structural geology (lineaments), etc. Lineament structures are crucial in site selection because their knowledge will help to curtail pollution of groundwater. However, the use of geophysical methods, especially by geo-electrical means, have proven their credibility in landfill-related studies, and become standard tools over the past decades in the determination of credible sites locations for landfills [7-10].

\subsection{Literature Review}

Research studies are available on MSW generation and management in developing countries such as Nigeria with each country having peculiar ways of handling their own waste. Among the studies are those that reveal how MSW defied several governments' laws and policies at different points in time [11]. The use of geophysical methods in landfill site investigation was carried out in Ibadan, Southwest Nigeria [12]. The work was carried out to provide detailed information on the suitability or otherwise the location for disposal of waste with utmost priority of preventing groundwater pollution. In their subsurface probe, 62 Very Low Frequency-Electromagnetic (VLF-EM) and 36 Vertical Electrical Soundings (VES) were used to determine the presence of linear structures, layer resistivity, bedrock depth, depth and characteristics of unsaturated zone, identification of any confined perched water bearing strata and subsurface features. Remote sensing (RS) and geographic information system (GIS) was used to delineate Karu metropolis to suitably site a landfill in the area for disposing MSW [13].

However, few publications are available in the use of georesistivity method for the purpose of landfill site selection for MSW disposal. This paper intends to bridge a gap to further add to the existing knowledge bank for site selection of landfills for future references. This forms the main objective of this paper which we believe will trigger further and detailed investigations in the years to come.

\section{Location, Geology and Hydrogeology}

\subsection{Location}

The study area is located in Lafia Local Government Area of Nasarawa State in Central Nigeria. It lies between between latitudes $8^{\circ} 30^{\prime} 00^{\prime \prime} \mathrm{N}$ to $8^{\circ} 36^{\prime} 10^{\prime \prime} \mathrm{N}$ and longitudes $8^{\circ} 30^{\prime} 00^{\prime \prime} \mathrm{E}$ to $8^{\circ} 35^{\prime} 40^{\prime \prime} \mathrm{E}$, having an area extent of about $100 \mathrm{Km}^{2}$ (Figure 1). The mean annual temperature and mean annual rainfall of Lafia are $28.5^{\circ} \mathrm{C}$ and $1250 \mathrm{~mm}$ respectively [14]. The surrounding topography is almost flat to a great extent, slightly high in the south-eastern parts of the study area than in the north-western. Table 1 shows comprehensive information on the locations the VES and water level surveys from hand dug wells.

\subsection{Geology}

The study area which is characterized by ferruginized sandstones, red loose sands, flaggy mudstones and clays, is made up of two formations (Figure 1): the older Awgu Formation of Late Turonian - Early Santonian is coalbearing while the younger Lafia Formation which is Maastrichtian in age ended the sedimentation in the Middle Benue Trough [15]. Awgu Formation was reviewed to be deposited in a marine environment and it consists of shale clays, siltstones and shelly limestones with some coals while the Lafia Sandstone which was deposited in a continental environment consisting of coarse grained, friable and feldspathic [16].

Being part of a larger sedimentary terrain, this area falls within the Middle Benue Trough of the Benue Valley of North-central Nigeria (Figure 2). The Benue Valley is widely believed to have evolved from a kind of rift structure due to a major fault along it [17]. Some authors postulated that what gave rise to the Benue Valley was sea floor spreading occasioned by the opening of the rift in the Cretaceous. This Benue Valley has rich documentations that are interesting and is worth studying in details.

\subsection{Hydrogeology}

The hydrogeology of the study area also follows that of the entire Benue Trough. The Lafia Formation is hydrogeologically viable because it is composed of majorly fine to coarse grain sandstones that are porously permeable 
for aquifers. The Middle Benue and other parts of the valley present difficult hydrogeological situations [16]. These ugly conditions become worrisome because most of the aquifers are either limited in capacity, thinly developed with constant clay and shale interbeddings or highly indurated formations that only secondary voids created by fractures, joints and solution openings can be hydrogeologically viable. Groundwater disposition of the Lafia Formation and other associated attributes was reviewed and there it revealed the presence of groundwater divides, like that of the Agyaragu
Divide which separates the Lafia sub-basin from the main centre of the Giza basin [18]. It was observed that the groundwater flow recharges the Lafia sub-basin directly thereby making the bulk of the flow to emerge in the form of many springs at the contact with the impervious clays/shale beds of the Awgu Formation. The clay/shale formation in this study area poses great threats to hydrogeological potentials of Lafia and environs as it limits groundwater exploration of the area.

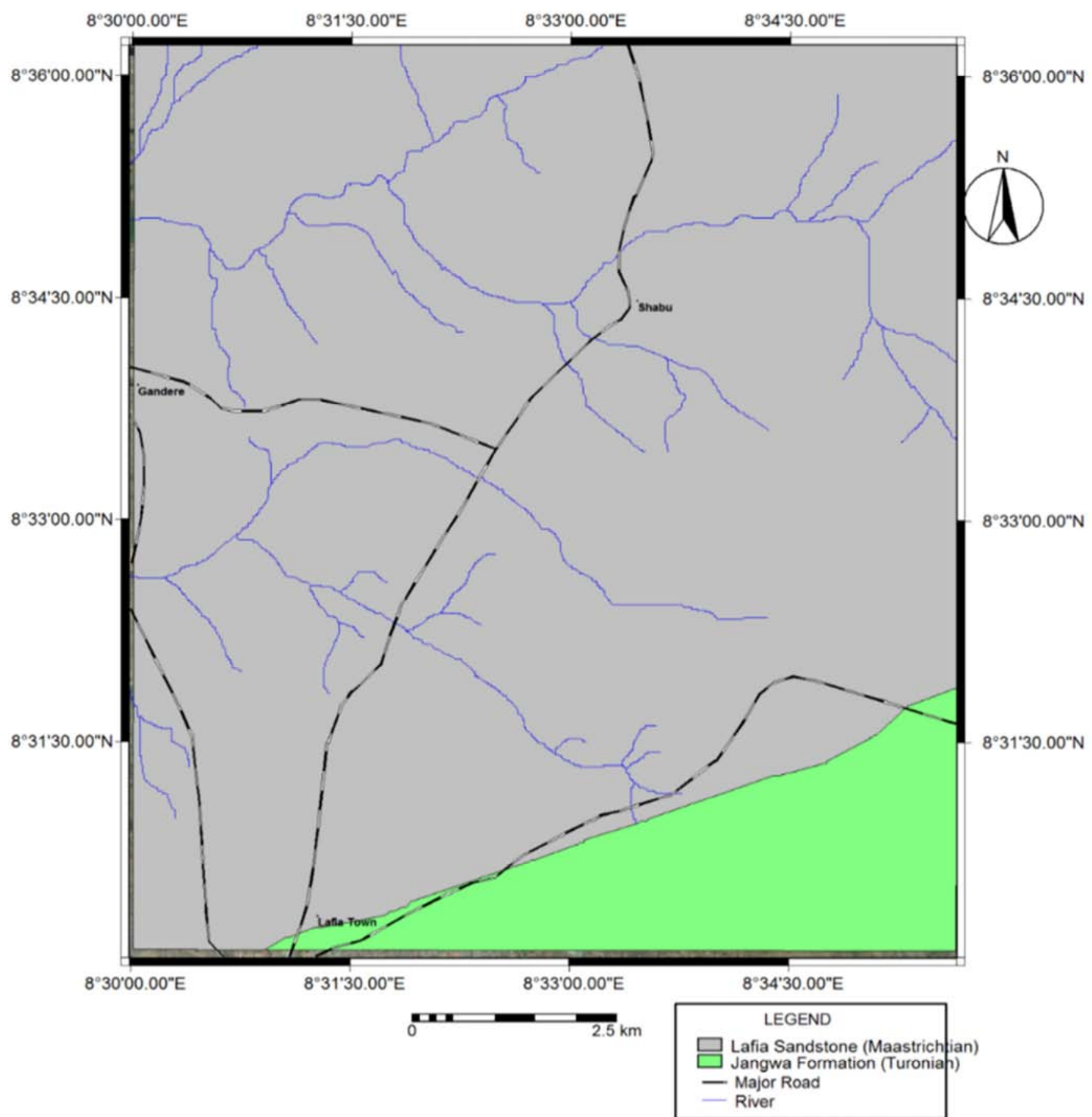

Figure 1. Geological Map of Study Area Showing the Two Formations. 
Table 1. Location of Vertical Electrical Sounding (VES) and Static Water Level (SWL) Measurement.

\begin{tabular}{|c|c|c|c|c|c|}
\hline Location & Survey Type & VES and HDW No. & Latitude (N) & Longitude (E) & Elevation $(\mathrm{m})$ \\
\hline Azuba & Vertical electrical sounding & VES 1 & $8^{\circ} 35^{\prime} 43.7^{\prime \prime}$ & $8^{\circ} 34^{\prime} 11.5^{\prime \prime}$ & 190 \\
\hline Kwandare II & VES & VES 2 & $8^{\circ} 35^{\prime} 03.8^{\prime \prime}$ & $8^{\circ} 30^{\prime} 57.8^{\prime \prime}$ & 140 \\
\hline Kwandare I & & VES 3 & $8^{\circ} 33^{\prime} 57.2^{\prime \prime}$ & $8^{\circ} 30^{\prime} 35.0^{\prime \prime}$ & 154 \\
\hline Akurba I & & VES 4 & $8^{\circ} 31^{\prime} 40.9^{\prime \prime}$ & $8^{\circ} 34^{\prime} 27.5^{\prime \prime}$ & 228 \\
\hline Akurba II & & VES 5 & $8^{\circ} 30^{\prime} 45.3^{\prime \prime}$ & $8^{\circ} 34^{\prime} 43.1^{\prime \prime}$ & 226 \\
\hline AgwanRere & & VES 6 & $8^{\circ} 31^{\prime} 12.8^{\prime \prime}$ & $8^{\circ} 35^{\prime} 34.5^{\prime \prime}$ & 258 \\
\hline AkurbaSanya & & VES 7 & $8^{\circ} 33^{\prime} 06.2^{\prime \prime}$ & $8^{\circ} 35^{\prime} 12.1^{\prime \prime}$ & 191 \\
\hline Shend. Road & & VES 8 & $8^{\circ} 30^{\prime} 54.3^{\prime \prime}$ & $8^{\circ} 33^{\prime} 01.8^{\prime \prime}$ & 202 \\
\hline Polytechnic & & VES 9 & $8^{\circ} 32^{\prime} 30.2^{\prime \prime}$ & $8^{\circ} 32^{\prime} 46.4^{\prime \prime}$ & 190 \\
\hline Shabu & & VES 10 & $8^{\circ} 34^{\prime} 41.7^{\prime \prime}$ & $8^{\circ} 33^{\prime} 47.0^{\prime \prime}$ & 164 \\
\hline \multirow[t]{9}{*}{ Azuba-Bashayi } & Hand dug well & HDW 1 & $8^{\circ} 35^{\prime} 20.4^{\prime \prime}$ & $8^{\circ} 33^{\prime} 25.1^{\prime \prime}$ & 165 \\
\hline & (HDW) & HDW 2 & $8^{\circ} 35^{\prime} 32.8^{\prime \prime}$ & $8^{\circ} 33^{\prime} 40.7^{\prime \prime}$ & 166 \\
\hline & & HDW 3 & $8^{\circ} 35^{\prime} 40.6^{\prime \prime}$ & $8^{\circ} 34^{\prime} 3.7^{\prime \prime}$ & 171 \\
\hline & & HDW 4 & $8^{\circ} 35^{\prime} 43.8^{\prime \prime}$ & $8^{\circ} 34^{\prime} 10.9^{\prime \prime}$ & 172 \\
\hline & & HDW 5 & $8^{\circ} 35^{\prime} 44.6^{\prime \prime}$ & $8^{\circ} 34^{\prime} 9.6^{\prime \prime}$ & 172 \\
\hline & & HDW 6 & $8^{\circ} 35^{\prime} 45.1^{\prime \prime}$ & $8^{\circ} 33^{\prime} 54.4^{\prime \prime}$ & 161 \\
\hline & & HDW 7 & $8^{\circ} 35^{\prime} 37^{\prime \prime}$ & $8^{\circ} 33^{\prime} 33.7^{\prime \prime}$ & 158 \\
\hline & & HDW 8 & $8^{\circ} 35^{\prime} 28.0^{\prime \prime}$ & $8^{\circ} 33^{\prime} 15.4^{\prime \prime}$ & 157 \\
\hline & & HDW 9 & $8^{\circ} 35^{\prime} 24.5^{\prime \prime}$ & $8^{\circ} 33^{\prime} 10.2^{\prime \prime}$ & 162 \\
\hline \multirow[t]{2}{*}{ Shabu } & & HDW 10 & $8^{\circ} 34^{\prime} 27.4^{\prime \prime}$ & $8^{\circ} 33^{\prime} 35.8^{\prime \prime}$ & 155 \\
\hline & & HDW 11 & $8^{\circ} 34^{\prime} 26.0^{\prime \prime}$ & $8^{\circ} 33^{\prime} 40.1^{\prime \prime}$ & 160 \\
\hline \multirow[t]{3}{*}{ Coll. of Agric. } & & HDW 12 & $8^{\circ} 33^{\prime} 47.6^{\prime \prime}$ & $8^{\circ} 32^{\prime} 29.6^{\prime \prime}$ & 163 \\
\hline & & HDW 13 & $8^{\circ} 33^{\prime} 43.7^{\prime \prime}$ & $8^{\circ} 32^{\prime} 29.3^{\prime \prime}$ & 158 \\
\hline & & HDW 14 & $8^{\circ} 33^{\prime} 44.0^{\prime \prime}$ & $8^{\circ} 32^{\prime} 23.8^{\prime \prime}$ & 173 \\
\hline Danka Sarki & & HDW 15 & $8^{\circ} 33^{\prime} 47.8^{\prime \prime}$ & $8^{\circ} 31^{\prime} 10.0^{\prime \prime}$ & 162 \\
\hline Kwandare & & HDW 16 & $8^{\circ} 34^{\prime} 0.5^{\prime \prime}$ & $8^{\circ} 30^{\prime} 21.6^{\prime \prime}$ & 157 \\
\hline \multirow[t]{4}{*}{ Polythecnic } & & HDW 17 & $8^{\circ} 33^{\prime} 1.2^{\prime \prime}$ & $8^{\circ} 32^{\prime} 3.7^{\prime \prime}$ & 182 \\
\hline & & HDW 18 & $8^{\circ} 33^{\prime} 1.4^{\prime \prime}$ & $8^{\circ} 32^{\prime} 4.3^{\prime \prime}$ & 178 \\
\hline & & HDW 19 & $8^{\circ} 32^{\prime} 51.7^{\prime \prime}$ & $8^{\circ} 32^{\prime} 18.5^{\prime \prime}$ & 189 \\
\hline & & HDW 20 & $8^{\circ} 32^{\prime} 51.5^{\prime \prime}$ & $8^{\circ} 32^{\prime} 21.1 "$ & 183 \\
\hline Kurkyo & & HDW 21 & $8^{\circ} 31^{\prime} 52.1^{\prime \prime}$ & $8^{\circ} 32^{\prime} 57.6^{\prime \prime}$ & 187 \\
\hline \multirow[t]{2}{*}{ Akurba } & & HDW 22 & $8^{\circ} 31^{\prime} 42.8^{\prime \prime}$ & $8^{\circ} 34^{\prime} 25.6^{\prime \prime}$ & 220 \\
\hline & & HDW 23 & $8^{\circ} 31^{\prime} 35.9^{\prime \prime}$ & $8^{\circ} 34^{\prime} 25.4^{\prime \prime}$ & 222 \\
\hline AngwanRere & & HDW 24 & $8^{\circ} 31^{\prime} 26.3^{\prime \prime}$ & $8^{\circ} 35^{\prime} 32.8^{\prime \prime}$ & 243 \\
\hline AkurbaSanya & & HDW 25 & $8^{\circ} 33^{\prime} 8.4^{\prime \prime}$ & $8^{\circ} 35^{\prime} 15.3^{\prime \prime}$ & 191 \\
\hline \multirow[t]{11}{*}{ BukanSidi } & & HDW 26 & $8^{\circ} 31^{\prime} 50.6^{\prime \prime}$ & $8^{\circ} 31^{\prime} 26.9^{\prime \prime}$ & 163 \\
\hline & & HDW 27 & $8^{\circ} 31^{\prime} 45.7^{\prime \prime}$ & $8^{\circ} 31^{\prime} 27.7^{\prime \prime}$ & 162 \\
\hline & & HDW 28 & $8^{\circ} 31^{\prime} 45.5^{\prime \prime}$ & $8^{\circ} 31^{\prime} 17.3^{\prime \prime}$ & 169 \\
\hline & & HDW 29 & $8^{\circ} 31^{\prime} 46.4^{\prime \prime}$ & $8^{\circ} 31^{\prime} 07.4^{\prime \prime}$ & 171 \\
\hline & & HDW 30 & $8^{\circ} 31^{\prime} 37.3^{\prime \prime}$ & $8^{\circ} 31^{\prime} 04.9^{\prime \prime}$ & 174 \\
\hline & & HDW 31 & $8^{\circ} 31^{\prime} 25.3^{\prime \prime}$ & $8^{\circ} 31^{\prime} 29 . "$ & 173 \\
\hline & & HDW 32 & $8^{\circ} 31^{\prime} 29.5^{\prime \prime}$ & $8^{\circ} 31^{\prime} 28.0^{\prime \prime}$ & 175 \\
\hline & & HDW 33 & $8^{\circ} 31$ '29.1" & $8^{\circ} 31^{\prime} 25.8^{\prime \prime}$ & 181 \\
\hline & & HDW 34 & $8^{\circ} 31^{\prime} 28.3^{\prime \prime}$ & $8^{\circ} 31^{\prime} 32.3^{\prime \prime}$ & 178 \\
\hline & & HDW 35 & $8^{\circ} 31^{\prime} 19.2^{\prime \prime}$ & $8^{\circ} 31^{\prime} 46.6^{\prime \prime}$ & 184 \\
\hline & & HDW 36 & $8^{\circ} 31^{\prime 2} 20.4^{\prime \prime}$ & $8^{\circ} 31^{\prime} 42.7^{\prime \prime}$ & 182 \\
\hline \multirow[t]{6}{*}{ Kurkyo } & & HDW 37 & $8^{\circ} 31^{\prime} 45.8^{\prime \prime}$ & $8^{\circ} 32^{\prime} 45.8^{\prime \prime}$ & 180 \\
\hline & & HDW 38 & $8^{\circ} 31^{\prime} 47.0^{\prime \prime}$ & $8^{\circ} 32^{\prime} 44.6^{\prime \prime}$ & 180 \\
\hline & & HDW 39 & $8^{\circ} 31^{\prime} 47.8^{\prime \prime}$ & $8^{\circ} 32^{\prime} 48.8^{\prime \prime}$ & 177 \\
\hline & & HDW 40 & $8^{\circ} 31^{\prime} 49.4^{\prime \prime}$ & $8^{\circ} 32^{\prime} 49.1^{\prime \prime}$ & 180 \\
\hline & & HDW 41 & $8^{\circ} 31^{\prime} 49.6^{\prime \prime}$ & $8^{\circ} 32^{\prime} 53.8^{\prime \prime}$ & 188 \\
\hline & & HDW 42 & $8^{\circ} 31^{\prime} 45.1^{\prime \prime}$ & $8^{\circ} 32^{\prime} 46.4^{\prime \prime}$ & 188 \\
\hline \multirow[t]{3}{*}{ BukanSidi } & & HDW 43 & $8^{\circ} 31^{\prime} 39.9^{\prime \prime}$ & $8^{\circ} 31^{\prime} 47.9^{\prime \prime}$ & 184 \\
\hline & & HDW 44 & $8^{\circ} 31^{\prime} 43.8^{\prime \prime}$ & $8^{\circ} 31^{\prime} 36.1^{\prime \prime}$ & 170 \\
\hline & & HDW 45 & $8^{\circ} 31^{\prime} 39.7^{\prime \prime}$ & $8^{\circ} 31^{\prime} 34.6^{\prime \prime}$ & 168 \\
\hline \multirow[t]{3}{*}{ Akurba } & & HDW 46 & $8^{\circ} 31^{\prime} 49.3^{\prime \prime}$ & $8^{\circ} 34^{\prime} 16.1 "$ & 212 \\
\hline & & HDW 47 & $8^{\circ} 31^{\prime} 52.2^{\prime \prime}$ & $8^{\circ} 34^{\prime} 16.2^{\prime \prime}$ & 201 \\
\hline & & HDW 48 & $8^{\circ} 31^{\prime} 58.9^{\prime \prime}$ & $8^{\circ} 34^{\prime} 17.8^{\prime \prime}$ & 198 \\
\hline \multirow[t]{3}{*}{ AngwanRere } & & HDW 49 & $8^{\circ} 31^{\prime} 27.8^{\prime \prime}$ & $8^{\circ} 35^{\prime} 40.4^{\prime \prime}$ & 243 \\
\hline & & HDW 50 & $8^{\circ} 31^{\prime} 24.7^{\prime \prime}$ & $8^{\circ} 35^{\prime} 44.8^{\prime \prime}$ & 244 \\
\hline & & HDW 51 & $8^{\circ} 31^{\prime} 24.5^{\prime \prime}$ & $8^{\circ} 35^{\prime} 48.5^{\prime \prime}$ & 246 \\
\hline
\end{tabular}



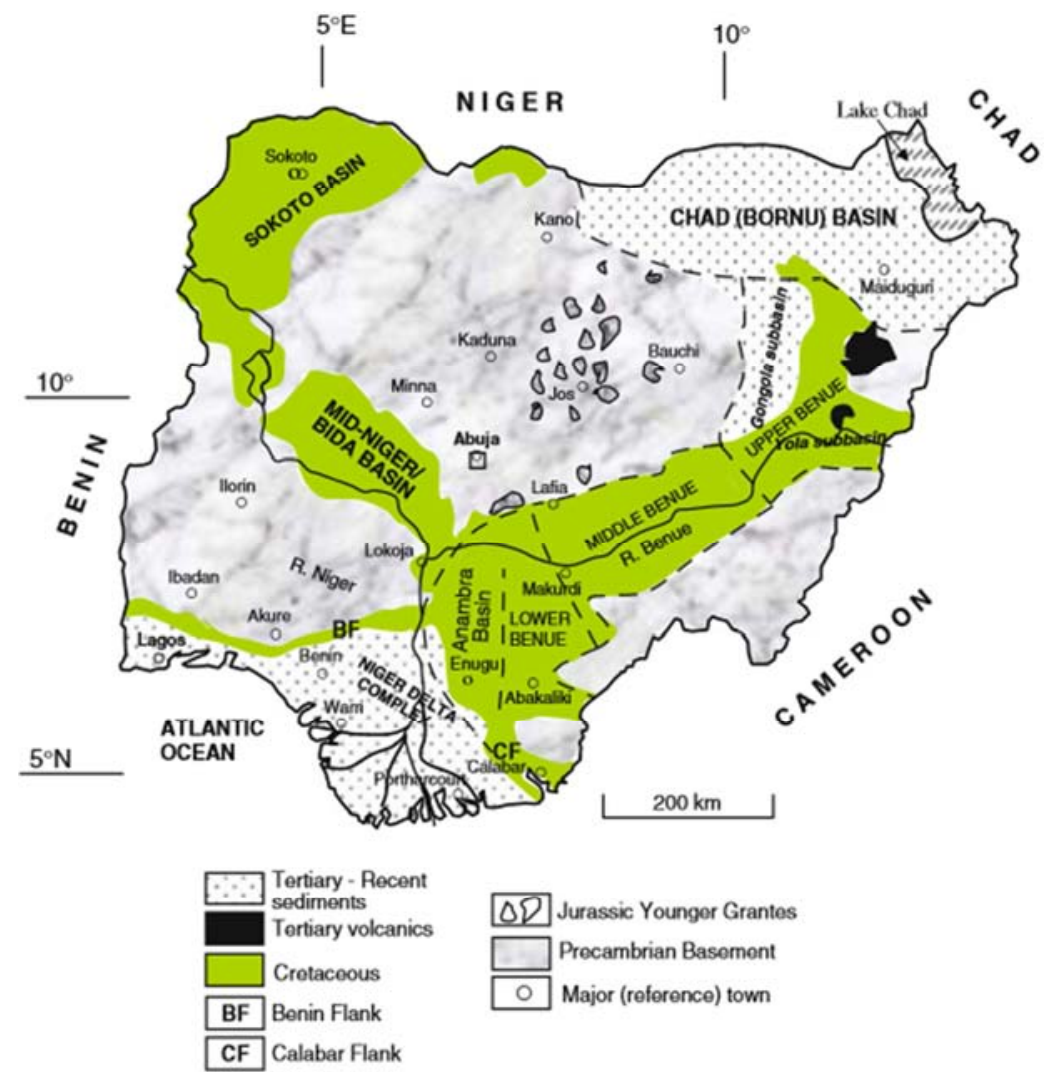

Figure 2. Geological Map of Nigeria Showing the sub-divisions along the Benue Trough (after [19]).

\section{Materials and Methods}

A total of ten Vertical Electrical Sounding (VES) stations were selected for the survey in the study area (Figure 4). The VES data for this study was obtained from using Schlumberger electrode array (Figure 3). Two electrodes each of potential and current were inserted and arranged such that the potential electrodes were positioned between the current electrodes. A measuring tape was used to rightly position both potential and current electrodes. The Avant Garde Resistivity meter was used to collect the data of the survey; this instrument generally measures the apparent resistivity of the subsurface lithology. The potential electrodes and current electrodes were connected to the potential terminal and current terminal respectively on the resistivity meter via the insulated copper cable wires.

During the survey, an artificially generated low frequency Direct Current (DC) was injected into the subsurface through a pair of current electrodes. The current electrodes half spacing $(\mathrm{AB} / 2)$ ranges from $1.0 \mathrm{~m}$ to $200.0 \mathrm{~m}$ in successive manner and the potential difference that was generated between a pair of potential electrodes (MN/2) was measured. Coordinates of each VES station were written down together with their individual elevations using the Garmin Global Positioning System (GPS) device. Data that was generated from the survey was later plotted on a log-log graph sheet, placing the apparent resistivity $\left(\rho_{\mathrm{a}}\right)$ values on the $y$-axis while the current electrodes spacing $(\mathrm{AB} / 2)$ on the $x$-axis. Plotted curves were interpreted quantitatively through partial curve matching. The results were further iterated using the iPi2win computer software. Pseudo resistivity cross-sections connecting more than two VES stations were later plotted and interpreted to a give a visual presentation of the subsurface of the preferred line of interest (Figure 4). The penetration depth of the current injected into the subsurface is proportional to the separation between the electrodes inserted in the homogeneous underlying layers while changing the current electrodes distance provides information about the distinct layers of the ground [20].

The geological mapping was carried out purposely to delineate and expose the major structural features in the study area. Lineament structures were identified and their direction orientations were also noted. Satellite image of the study area was obtained and subsequently, the lineament structures were traced and super-imposed on the topographical map to produce the lineament map. Lineaments are naturally occurring alignments of soil tones, topography, stream channels, vegetation or combinations of these fractures that are visible on remotely sensed imagery and aerial photographs. Presumably, the geomorphic expressions observed from lineaments features on satellite imageries are due to differential weathering with the fractures zones being readily susceptible to both mechanical and chemical weathering than unfractured rocks [21]. After producing the lineament map, it was further sub-divided into four parts so that each lineament structure in each quadrant is analysed in terms of the amount of degrees and direction of orientation by the use of a protractor and compass 
respectively. The main assumption inherent in performing any lineament analysis is that these alignments represent fracture zones (areas of intense, closely spaced fracturing) or other discontinuities (faults, geologic contacts) in the bedrocks that may be capable of transmitting groundwater or leachates to landfills as in the case of this paper. Data from the analysis was plotted on a rosette diagram to give a vivid picture of the structural trend generally.

The hydrogeological investigation involved the mapping of a total of fifty-one Hand Dug Wells (HDW) within the study area. The Static Water Level (SWL) of each HDW was measured by using a measuring tape with a dipper tied to the end measuring tape in meter. Once the measuring tape is lowered into the HDW and the dipper touches the water, the SWL is established. The coordinates and elevations above sea level of each of these wells were recorded. Absolute Water Level (AWL) of awell was calculated by subtracting the SWL from the elevation of that particular well. It is a dimensionless quantity. One of the uses of the hydrogeological investigation using the HDW is to determine water flow direction in the study area aside other uses that it has. Data generated from this survey were used to construct a water flow direction in a $3 \mathrm{D}$ presentation to grasp the pictorial and vivid presentation of the hydrogeological mapping of the study area.

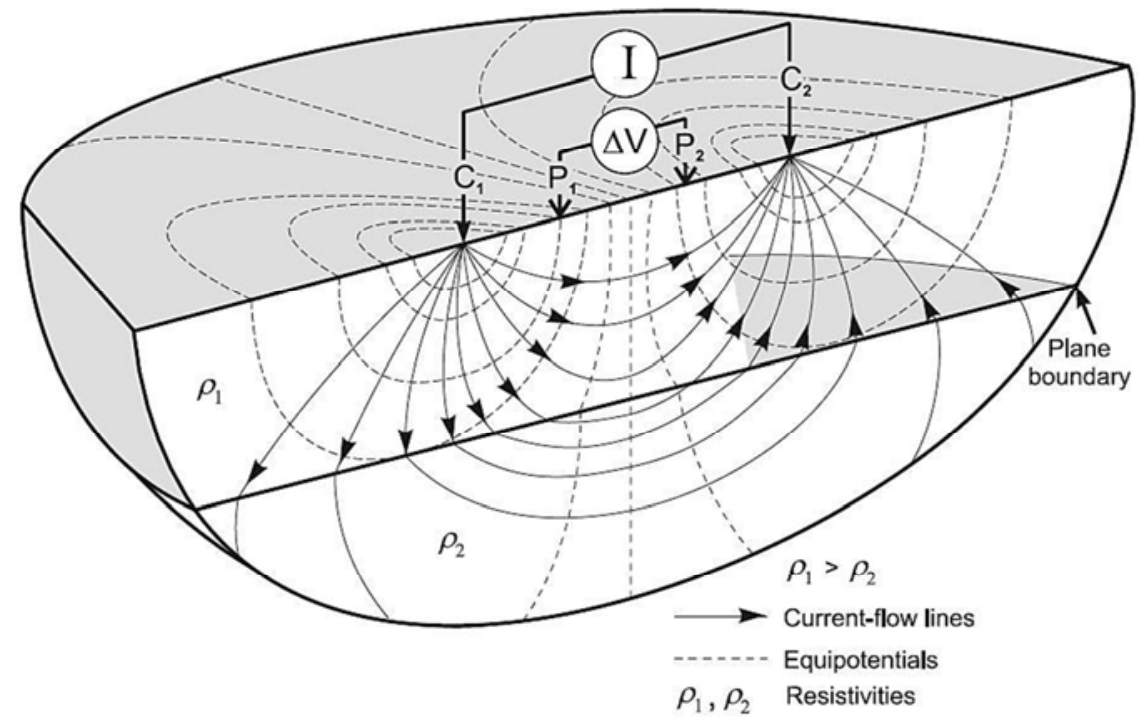

Figure 3. Schematic Diagram of Electrical Resistivity Using the Schlumberger Array (after [22]).

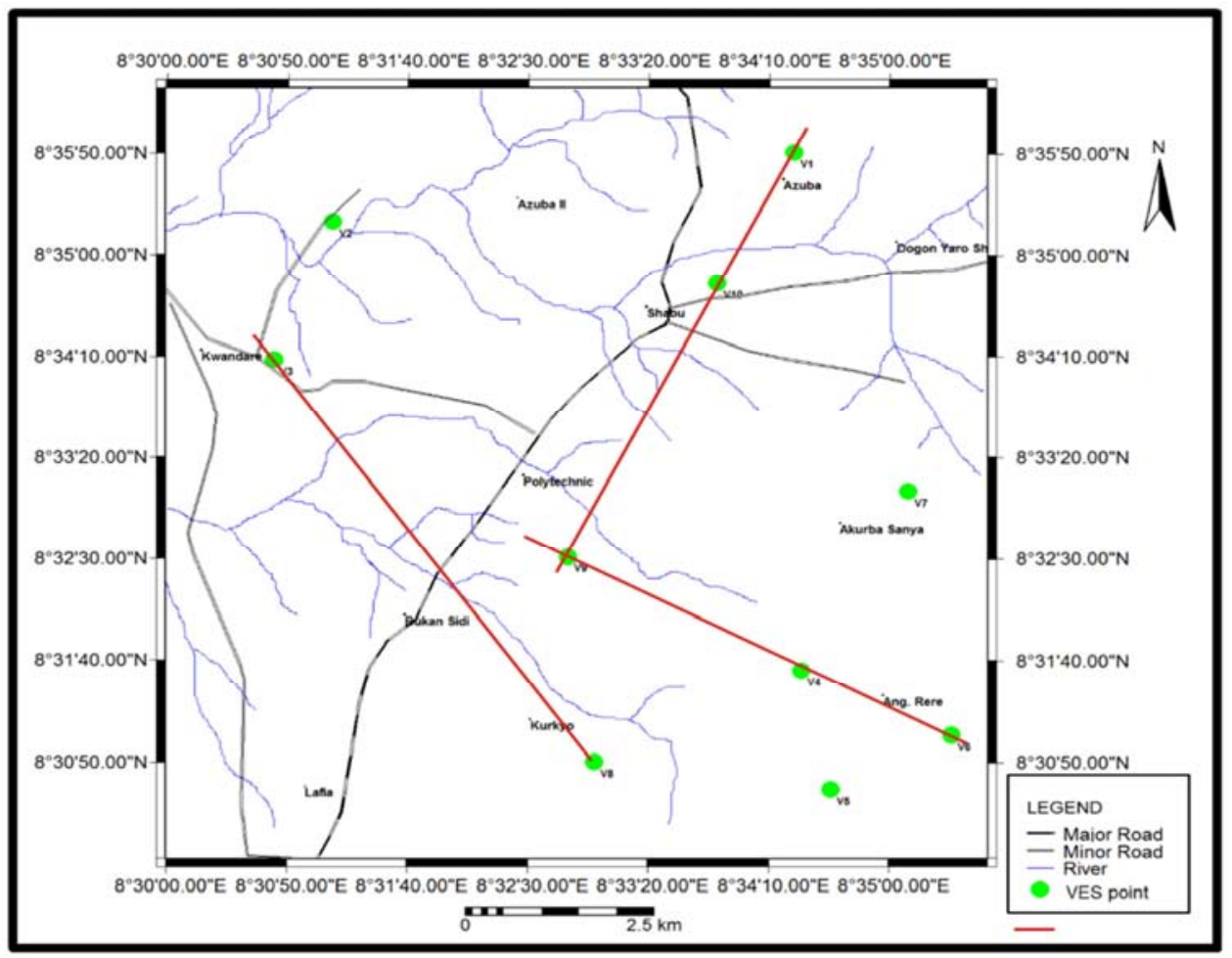

Figure 4. Map of Study Area Showing Locations ofVES Points with profile Lines for Pseudo-Sections. 


\section{Results and Discussion}

\subsection{Electrical Resistivity}

Table 2 shows data generated from the ten VES stations of the study area. Quantitative interpretations of the VES show curve types that indicate $4-5$ distinct geo-electric layers. The curve types are KQ, $\mathrm{QH}, \mathrm{AK}, \mathrm{KH}$ and $\mathrm{HK}$, with a representative shown in figure 5. Analyses of the resistivity results layer by layer are as follows: (i) The resistivity of the sandy topsoil layer varies from $247-1964 \Omega \mathrm{m}$ with thickness ranging from $3.5-10.5 \mathrm{~m}$; (ii) the second layer which is composed of silty sand has its resistivity varying from 98 $3488 \Omega \mathrm{m}$ and thickness ranging from $7.0-24.0 \mathrm{~m}$; (iii) the third layer is composed of clayey/sand whose resistivity varies from $68-3922 \Omega \mathrm{m}$ and the thickness ranges from 33.0 - 63.0 $\mathrm{m}$; (iv) the saturated clayey sand comprise the fourth layer and has resistivity varying from $31-3226 \Omega \mathrm{m}$ and thickness ranges from $37.0 \mathrm{~m}-\infty$; and (v) loose/shaley sand is the fifth layer whose resistivity value is $478 \Omega \mathrm{m}$ with thicknesses placed at infinity which is peculiar of VES 8 only.

Since emphasis is placed on clay as key to siting a landfill, some of the VES stations such as VES 1, 2, 3, 9 and 10 revealed from the survey, to have abundant clay (Table 1). Clay present in VES 1 has resistivity value of $31 \Omega \mathrm{m}$ and a depth at infinity; at VES 2, the resistivity of clay is $21 \Omega \mathrm{m}$ and it lies at infinity depth; at VES 3 clay was also found to be at infinity depth but has a resistivity value of $23 \Omega \mathrm{m}$; clay layer found at VES 9 has a resistivity value of $58 \Omega \mathrm{m}$ also at infinity depth; however, clay found at VES 10 located at Shabu, has a resistivity value of $98 \Omega \mathrm{m}$ and slightly buried at a shallow depth of $25.5 \mathrm{~m}$. This is good for a landfill facility.

The pseudo-resistivity sections of some profile lines were plotted in $2 \mathrm{D}$, were generated from the data in figure 4 above. Three profile lines were able to be extracted from figure 4 as shown by the red lines running joining points on the map. These lines include profile line through VES 1, 10 and 10; VES 9, 4 and 6; VES 3 and 8. The best profile line of interest is that that connects VES 1, 10 and 9. This profile line clearly shows the pseudo-resistivity section of the lithostratigraphy of the subsurface (Figure 6). This pictorial presentation shows clay layer (black/blue coloration layer) that stretches throughout the line, and interestingly, at a depth of about $30 \mathrm{~m}$ substantial layer of clay was encountered which is ideal for siting a landfill.

Table 2. Results of VES

\begin{tabular}{|c|c|c|c|c|c|c|}
\hline VES No & Layer No. & Resistivity, $\rho(\Omega \mathrm{m})$ & Thickness, h (m) & Depth, d (m) & Inferred Geology & Type of Curve \\
\hline \multirow[t]{4}{*}{ VES 1} & 1 & 732 & 3.5 & 3.5 & Sandy top soil & KQ \\
\hline & 2 & 887 & 19 & 22.5 & Silty sand & \\
\hline & 3 & 326 & 36 & 55 & Shaley sand/Aquifer & \\
\hline & 4 & 31 & $\infty$ & $\infty$ & Clay & \\
\hline \multirow[t]{4}{*}{ VES 2} & 1 & 654 & 3.5 & 3.5 & Sandy top soil & KQ \\
\hline & 2 & 916 & 12 & 15.5 & Lateritic clay & \\
\hline & 3 & 186 & 33 & 45 & Sandy clay/Aquifer & \\
\hline & 4 & 21 & $\infty$ & $\infty$ & Clay & \\
\hline \multirow[t]{4}{*}{ VES 3} & 1 & 668 & 3.5 & 3.5 & Lateritic sand & $\mathrm{QH}$ \\
\hline & 2 & 277 & 7 & 10.5 & Sandy clay & \\
\hline & 3 & 44 & 33 & 40 & Clay sand/Aquifer & \\
\hline & 4 & 23 & $\infty$ & $\infty$ & Clay & \\
\hline \multirow[t]{4}{*}{ VES 4} & 1 & 1516 & 3.5 & 3.5 & Lateritic top soil & KQ \\
\hline & 2 & 2237 & 24 & 27.5 & Sandstone & \\
\hline & 3 & 1679 & 36 & 60 & Sandstone/Aquifer & \\
\hline & 4 & 1500 & $\infty$ & $\infty$ & Saturated sandstone & \\
\hline \multirow{4}{*}{ VES 5} & 1 & 342 & 5.5 & 5.5 & Shaley top soil & $\mathrm{AK}$ \\
\hline & 2 & 1178 & 17 & 22.5 & Loose sand & \\
\hline & 3 & 1677 & 33.5 & 50.5 & Sandstone/Aquifer & \\
\hline & 4 & 2291 & $\infty$ & $\infty$ & dry sandstone & \\
\hline \multirow[t]{4}{*}{ VES 6} & 1 & 1964 & 10.5 & 10.5 & Lateritic top soil & HK \\
\hline & 2 & 3488 & 33 & 43.5 & Dry Sandstone & \\
\hline & 3 & 3922 & 47 & 80 & Sandstone/Aquifer & \\
\hline & 4 & 3226 & $\infty$ & $\infty$ & Sandstone & \\
\hline \multirow[t]{4}{*}{ VES 7} & 1 & 756 & 3.5 & 3.5 & Clayey top Soil & $\mathrm{KH}$ \\
\hline & 2 & 1448 & 7 & 10.5 & Loose sand & \\
\hline & 3 & 510 & 63 & 70 & Shaley sand/Aquifer & \\
\hline & 4 & 303 & $\infty$ & $\infty$ & Shaley sand & \\
\hline \multirow[t]{4}{*}{ VES 8} & 1 & 247 & 3.5 & 3.5 & Silty top soil & $\mathrm{AK}$ \\
\hline & 2 & 799 & 7 & 10.5 & Fine sand & \\
\hline & 3 & 1154 & 63 & 70 & Loose sand & \\
\hline & 4 & 1202 & 37 & 100 & Sandstone/Aquifer & \\
\hline
\end{tabular}




\begin{tabular}{lllllll}
\hline VES No & Layer No. & Resistivity, $\boldsymbol{\rho}(\mathbf{\Omega m})$ & Thickness, $\mathbf{h}(\mathbf{m})$ & Depth, $\mathbf{d}(\mathbf{m})$ & Inferred Geology & Type of Curve \\
\hline \multirow{2}{*}{ VES 9} & 5 & 478 & $\infty$ & $\infty$ & Shaley sand & \\
& 1 & 421 & 4.5 & 4.5 & Sandy top Soil & KH \\
& 2 & 794 & 18 & 22.5 & Fine Sand & \\
& 3 & 258 & 62 & 80 & Sandy clay/Aquifer & \\
VES 10 & 4 & 58 & $\infty$ & $\infty$ & Clay & QH \\
& 1 & 673 & 6.5 & 6.5 & Sandy top soil & \\
& 2 & 98 & 19 & 25.5 & Clay & Clay/Aquifer \\
& 3 & 68 & 51 & 70 & Clay & \\
\hline
\end{tabular}

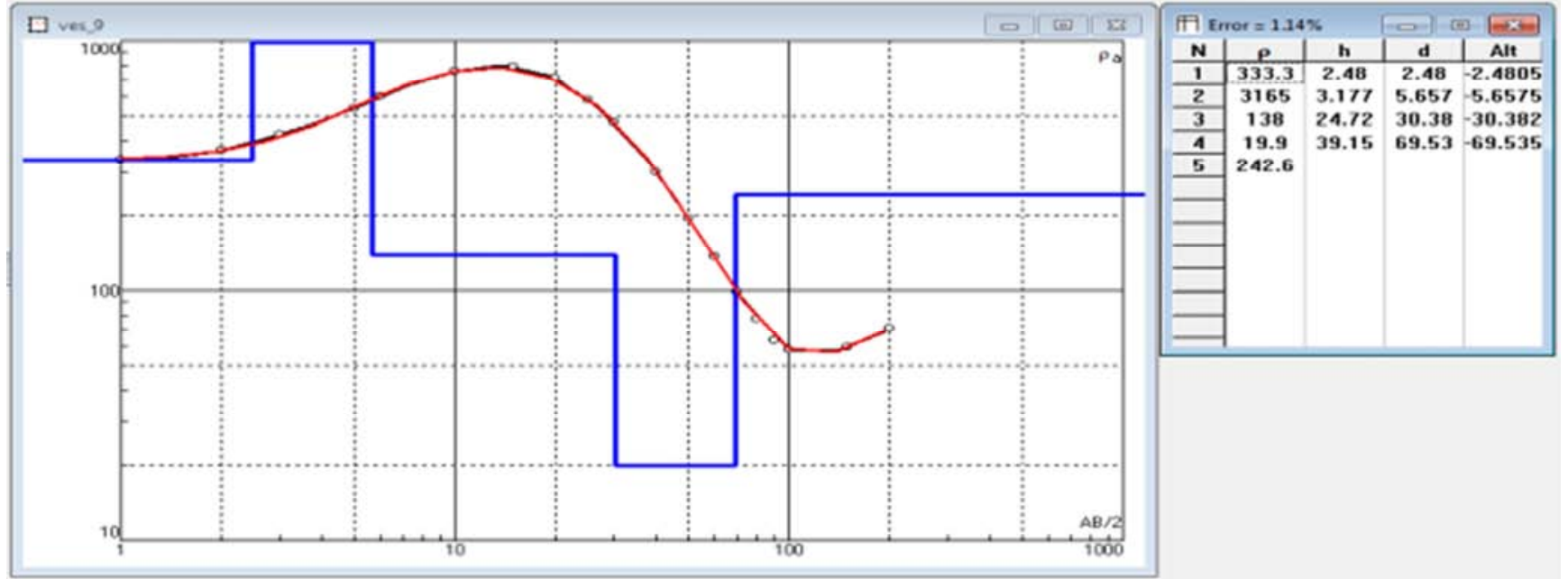

Figure 5. Representative Resistivity curve (KH curve).

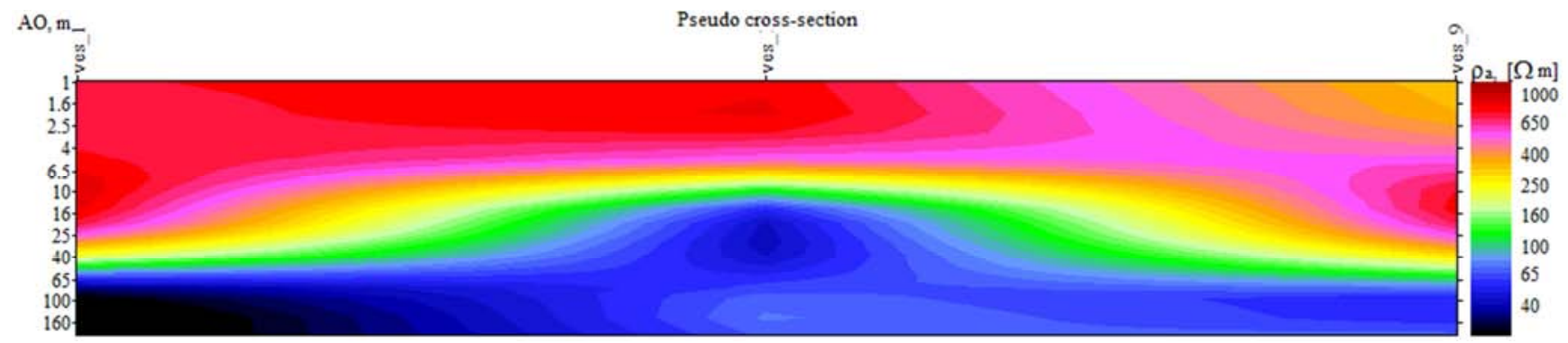

Figure 6. Pseudo-resistivity Section for Profile line through VES 1, 10 and 9.

\subsection{Geological (Lineament) Studies}

Data from lineament studies in table 3 indicate that the study area is underlain with geological structures (Figure 7) which may include fractures, faults, geologic contacts etc. The northern parts of the study area is highly characterized by many structures while the southern parts of the mapped area was observed to have a few number of lineament structures. Some trends of the lineaments measure $\mathrm{N} 105^{\circ} \mathrm{W}$, $\mathrm{N} 145^{\circ} \mathrm{W}, \mathrm{N} 100^{\circ} \mathrm{E}, \mathrm{N} 105^{\circ} \mathrm{E}, \mathrm{N} 180^{\circ} \mathrm{E}, \mathrm{N} 130^{\circ} \mathrm{W}$, etc with the use of a protractor. The analysis reveals the dominant trend to be NW - SE when plotted on the Rosette diagram (Figure 8). This dominant trend describes tectonically the effects of the lineaments to the flow patterns of streams and rivers systems in the study area. Notably, Shabu area lacks clusters of lineaments which make it good for landfill siting.

Table 3. Lineaments Trend Analysis.

\begin{tabular}{llll}
\hline S/No. & Trend Direction & Number of Lineaments & Percentage (\%) \\
\hline 1 & NE - SW & 35 & 23 \\
2 & NW - SE & 57 & 38 \\
3 & NNW - SSE & 26 & 17 \\
4 & ENE - WSW & 15 & 10 \\
5 & NNE - SSW & 16 & 11 \\
\hline
\end{tabular}




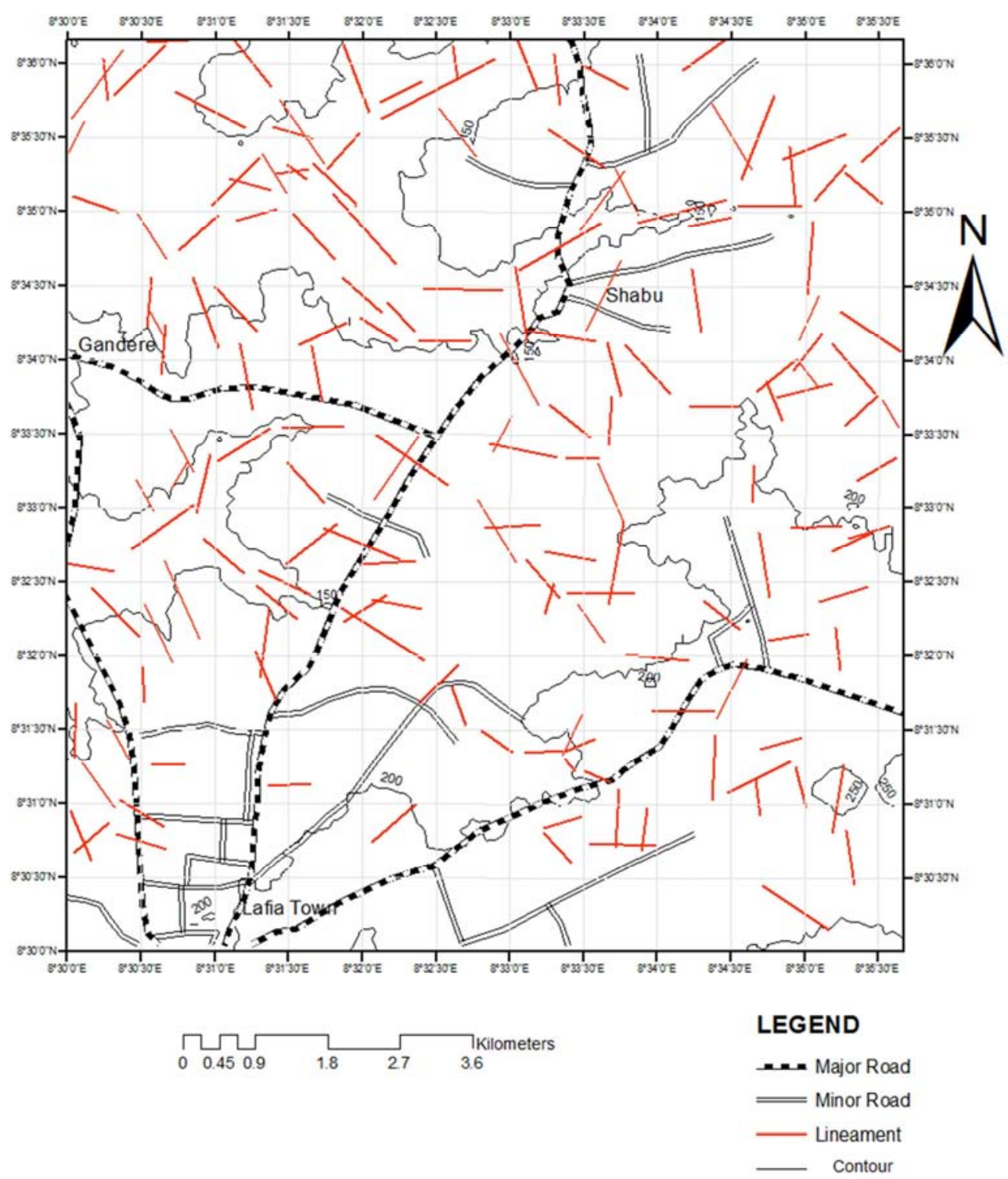

Figure 7. Map Showing Lineament Structures.

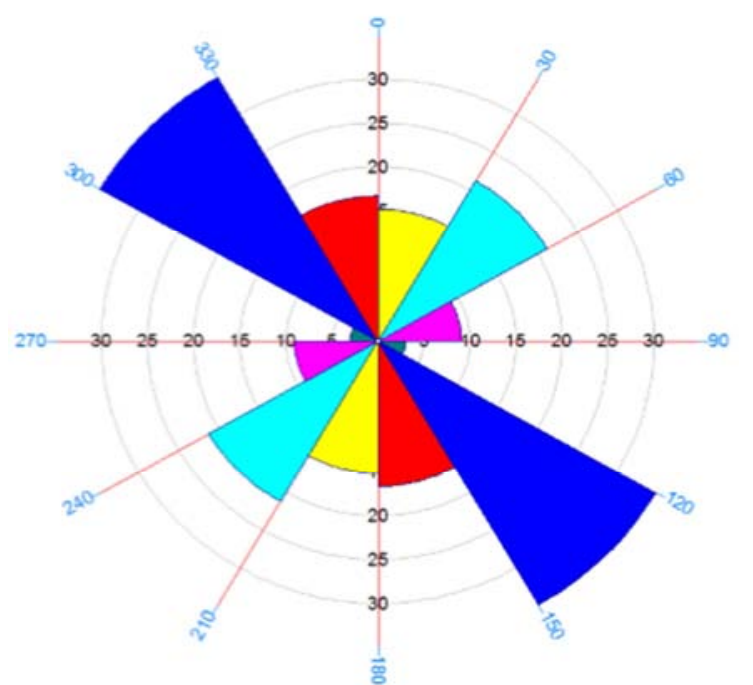

Figure 8. Rosette Diagram for Lineament Structures.

\subsection{Static Water Level (SWL)}

Table 4 shows the results of SWL obtained from 51 HDW of the study area. The mean SWL in the study area is measured at $12.3 \mathrm{~m}$ depth. These wells vary in depths due to their locations with respect to their elevations above sea level. Consequently, data from the table were used to construct the AWL map in figure 9.

The SWL map in figure 9 shows the groundwater distribution flow pattern of the study area. The groundwater flows from the eastern and southeastern parts (blue coloration area) of the map towards the western and northwestern parts (greenish area) of the map. This is particularly true as a result of the difference in elevation pattern of the area. It is evidently clear that the eastern and southeastern parts of the map have higher elevation coefficients than other parts of the map. Since groundwater flows in accordance with the surface topography and hydraulic head, it is forced to flow accordingly as represented by the arrows on the $3 \mathrm{D}$ map of 
the HDW below. This flow pattern is possible because the hydraulic head values were observed to be higher than 190 in these areas, which consequently implies that these areas are the recharge zones. On the other hand, western and northwestern parts of the map are lower in hydraulic head values and so the groundwater flows towards the area.

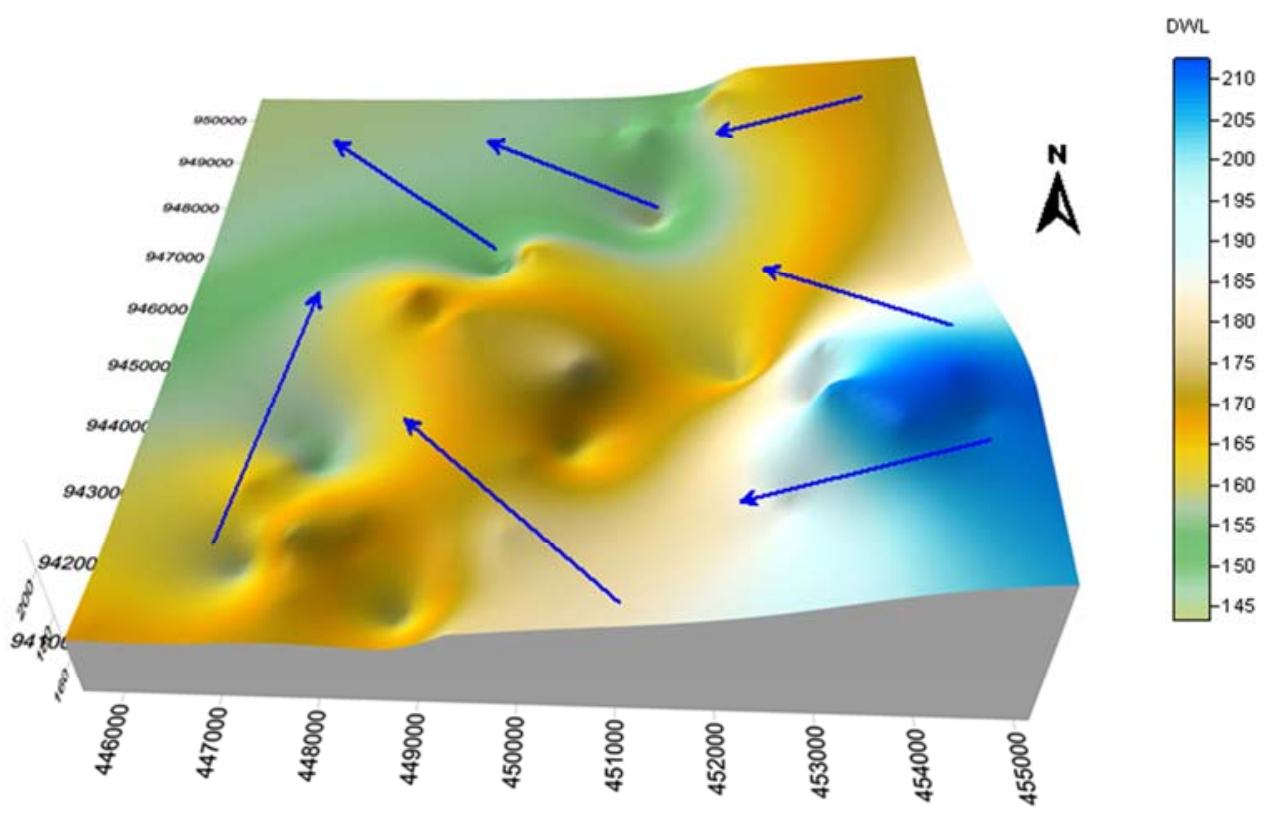

Figure 9. Map showing 3D Presentation of AWL the study Area.

Table 4. Results of Static Water Level (SWL) and Absolute Water Level $(A W L)$

\begin{tabular}{llll}
\hline HDW No & Elevation $(\mathbf{m})$ & SWL $(\mathbf{m})$ & AWL $(\mathbf{m})$ \\
\hline HDW 1 & 165.0 & 9.8 & 155.2 \\
HDW 2 & 166.0 & 18.2 & 147.8 \\
HDW 3 & 171.0 & 7.7 & 163.3 \\
HDW 4 & 172.0 & 9.0 & 163.0 \\
HDW 5 & 172.0 & 8.0 & 164.0 \\
HDW 6 & 161.0 & 7.7 & 153.3 \\
HDW 7 & 158.0 & 7.6 & 150.4 \\
HDW 8 & 157.0 & 9.1 & 147.9 \\
HDW 9 & 162.0 & 11.7 & 150.3 \\
HDW 10 & 155.0 & 12.0 & 143.0 \\
HDW 11 & 160.0 & 8.6 & 151.4 \\
HDW 12 & 163.0 & 5.8 & 157.2 \\
HDW 13 & 158.0 & 7.5 & 150.5 \\
HDW 14 & 173.0 & 9.0 & 164.0 \\
HDW 15 & 162.0 & 9.8 & 152.2 \\
HDW 16 & 157.0 & 9.8 & 147.2 \\
HDW 17 & 182.0 & 13.2 & 168.8 \\
HDW 18 & 178.0 & 13.5 & 164.5 \\
HDW 19 & 189.0 & 18.0 & 171.0 \\
HDW 20 & 183.0 & 11.0 & 172.0 \\
HDW 21 & 187.0 & 11.1 & 175.9 \\
HDW 22 & 220.0 & 10.8 & 209.2 \\
HDW 23 & 222.0 & 16.2 & 205.8 \\
HDW 24 & 243.0 & 32.3 & 210.7 \\
HDW 25 & 191.0 & 9.8 & 181.2 \\
HDW 26 & 163.0 & 8.9 & 154.1 \\
HDW 27 & 162.0 & 6.0 & 156.0 \\
HDW 28 & 169.0 & 7.3 & 161.7 \\
HDW 29 & 171.0 & 13.5 & 157.5 \\
HDW 30 & 174.0 & 8.5 & 165.5 \\
\hline & & &
\end{tabular}

\begin{tabular}{llll}
\hline HDW No & Elevation $(\mathbf{m})$ & SWL $(\mathbf{m})$ & AWL $(\mathbf{m})$ \\
\hline HDW 31 & 173.0 & 9.2 & 163.8 \\
HDW 32 & 175.0 & 8.2 & 166.8 \\
HDW 33 & 181.0 & 8.1 & 172.9 \\
HDW 34 & 178.0 & 8.3 & 169.7 \\
HDW 35 & 184.0 & 16.9 & 167.1 \\
HDW 36 & 182.0 & 14.2 & 167.8 \\
HDW 37 & 180.0 & 11.2 & 168.8 \\
HDW 38 & 180.0 & 10.4 & 169.6 \\
HDW 39 & 177.0 & 17.5 & 159.5 \\
HDW 40 & 180.0 & 11.5 & 168.5 \\
HDW 41 & 188.0 & 11.7 & 176.3 \\
HDW 42 & 188.0 & 11.9 & 176.1 \\
HDW 43 & 184.0 & 13.2 & 170.8 \\
HDW 44 & 170.0 & 8.1 & 161.9 \\
HDW 45 & 168.0 & 7.5 & 160.5 \\
HDW 46 & 212.0 & 14.6 & 197.4 \\
HDW 47 & 201.0 & 14.5 & 186.5 \\
HDW 48 & 198.0 & 11.6 & 186.4 \\
HDW 49 & 243.0 & 30.4 & 212.6 \\
HDW 50 & 244.0 & 33.0 & 211.0 \\
HDW 51 & 246.0 & 37.1 & 208.9 \\
\hline
\end{tabular}

\section{Summary and Conclusion}

With the prevalence of waste generation, it is pertinent to also find a way of adequately manage their disposal in a way that will protect the environment. The preliminary investigations of this study, which involve geo-resistivity data collection, geological (lineament) and static water level from HDW, were integrated and used to delineate Lafia and environs for the purpose of suitably siting a landfill to curb the indiscriminate disposal of MSW. Ten VES points were 
randomly sited to collect geo-resistivity data using the Schlumberger array. Computer software, IPI2win, was used for the quantitative interpretation. Four to five geo-electric layers were revealed in the survey of the VES stations. Curve types from the interpretation show KQ, QH, AK, KH and HK curve types. Since clay is vital to siting a landfill because of its roles in attenuating leachate flow, VES VES 1, 2, 3, 9 and 10 were found to contain abundance of clay however; clay was not discovered at VES 4, 5, 6, 8 and 7. Clay's resistivity values ranges between $21 \Omega \mathrm{m}$ to $68 \Omega \mathrm{m}$ and thickness is between $19 \mathrm{~m}$ and $51 \mathrm{~m}$. Of all the sounding stations, VES 10 located in Shabu particularly, gives a better result when it comes to depth of clay in the survey. The depth was the shallowest at about $25.5 \mathrm{~m}$ and will likely be reasonable to site a landfill there.

Geological investigation in the form if lineament studies revealed that the area is underlain with many structures which may include faults, fractures, folds, etc. Analysis of lineaments indicates a trend dominant in the NW-SE direction when plotted in the Rosette diagram. It also describes the control of the flow pattern of the rivers and streams systems in the study area. Their studies are important because they help to uncover the geological structures that lie beneath the surface which are channels that pollute groundwater quality by contaminating leachates pollution from landfills. Though lineaments were abundant in the study area, interestingly, Shabu was found to have less of the lineaments. This attribute makes Shabu a likely area suitable to site the facility.

The hydrogeological investigation revealed that most of the HDW studied in thearea only utilized shallow aquifers. The SWL found in the areas with rich-clay deposits range between $7.6 \mathrm{~m}$ and $18.2 \mathrm{~m}$.

In conclusion, this paper found out that Shabu, a town about $8 \mathrm{KM}$ located north of Lafia, is suitable for siting a landfill having taken into consideration the results from electric resistivity, geological and hydrogeological investigations.

\section{Recommendations}

These recommendations were deduced from the studies undertaken from the paper;

(i) Municipal Solid Waste management in Nasarawa State, especially in Lafia the state's capital, is poor because wastes disposal facilities, like landfills are not available for use.

(ii) Shabu, located at $8^{\circ} 34^{\prime} 41.7^{\prime \prime} \mathrm{N}, 8^{\circ} 33^{\prime} 47.0^{\prime \prime} \mathrm{E}, 8 \mathrm{Km}$ and NE from Lafia, is recommended for a landfill based on the findings of the geo-resistivity, geological, hydrogeological and structural investigations.

(iii) The combined parameters used for this study are inadequate for a detailed investigation because the findings here merely are preliminary ones: a detailed investigation should be conducted to review and validate the claims of the study.

(iv) Nasarawa State Government, corporate bodies and wealthy individuals can collaborate to find a lasting solution to this environmental menace by sponsoring scientific researches that have direct bearing on the lives of people and the environment.

\section{References}

[1] Dahlin, T. (2001). The development of DC resistivity imaging techniques; Comput. Geosci. 27, 1019-1029.

[2] Leton, T. G. and Omotosho, O. (2004). Landfill Operations in the Niger Delta Region of Nigeria. Engineering Geology 73 (1-2): 171-177.

[3] Amadi, A. N., Akande, W. G., Okunola, I. A., Jimoh, M. O. and Francis, D. G. (2015). Assessment of the geotechnical properties of lateritic soils Minna, North Central Nigeria for road design and construction. American Journal of Mining and Metallurgy, 3 (1), 15-20.

[4] Ukpon, E. C. U., Udo, E. A. and Umoh, I. C. (2015). Characterization of Materials from Aba Waste Dumpsites. Int. J. Eng. Applied. Sc. 6: 1-10.

[5] Odoemene, U. D. and Ofodu, J. (2016). Solid Waste Management in Aba Metropolis. Int. J. Adv. Acad. Res. 2: 1-7.

[6] Amadi, A. N., Nwankwoala, H. O., Eze, C. J., Alkali, Y. B. and Waziri, S. H., (2012a). A review of waste management techniques in parts of Niger Delta, Nigeria. Centre for Human Settlement and Urban Development Journal, 3 (1), 98-108.

[7] Loke, M. H. (1999). Electrical Imaging Surveys for Environmental and Engineering Studies, A Practical Guide to 2D and 3D Surveys. http://www.geoelectrical.com.

[8] Radulescu, M., Valerian, C. and Yang, J. (2007). Time Lapse Electrical Resistivity Anomalies due to Contaminant Transport Around Landfills, Annals of Geophysics, 50, 453-468.

[9] Zhu, K. and Yang, J. (2008). Time-Dependent Magnetic Resistivity Anomalies of Groundwater Contamination: Synthetic Results from Computational Hydro-Geophysical Modeling. Applied Geophysics 5, 322-336.

[10] Yang, J. W. and Joshi, S. D. (2014). Hydro-Geophysical Investigation of Contaminant Distribution at a closed landfill in Southwestern Ontario, Canada. Journal of Geosciences and Environmental Protection. 2, 8-15.

[11] Shuaibu, M. A. (2015). Geospatial Technology approach to Bauchi Metropolis Refuse Disposal and Sustainable Management, Unpublished $\mathrm{PhD}$ Thesis, Department of Surveying and Geoinformatics, Modibbo Adama, Univ. of Tech. Yola, Nigeria.

[12] Oyediran, I. A. and Adeyemi, G. O. (2011). Use of geophysical methods in landfill site investigation: a case study of Ibadan, South-western Nigeria. New York Science Journal, 4 (10), http://www.science pub.net/newyork.

[13] Rakiat, L. H., Alaga, T. A., Gajere, E. N., Ukor, C. and Amos, S. J. (2016). Landfill Site Selection for Solid Waste Management in Karu LGA, Nasarawa State, Nigeria; International Journal of Trend in Research and Development, Vol. 3 (6), pp 436-467.

[14] Binbol, N. L. (2006) A climate of Nasarawa State. Report of geographical prospective on Nas. State, Dept. of Geography, Nasarawa State University, Keffi. 
[15] Umar, N. D., Idris, I. G., Aliyu, M. K. and Idris, M. S. (2018). Assessment of aquifer protective capacity and corrosion potential using electrical resistivity techniques in the sandstone aquifer of Lafia and environs, Nasarawa State, Nigerian Journal of Physics, Vol 27 S, Pp 83-94.

[16] Offodile, M. E. (2002). Groundwater study and development in Nigeria, Published by Meacon Geology and Engineering Services Ltd., Jos, Nigeria.

[17] Carter, T. D., Barber, W. and Tait, E. A. (1963). The Geology of Parts of Adamawa, Bauchi and Bornu Provinces in NE Nig. Geol. Survey. Nigeria Bull, no. 30.

[18] Offodile, M. E. (1976). The geology of the Middle Benue of Nigeria. Publication of the Paleo. Inst. of the University of Uppsala Special Vol. No. 4, pp 146-160.
[19] Obaje, N. G. (2009). Geology and Mineral Resources of Nigeria. Springer- verlag Berlinheielberg. 221.

[20] Obiora, D. N., Ajala, A. E. and Ibuot, J. C. (2015). Evaluation of aquifer protective capacity of overburden unit and soil corrosivity in Markurdi, Benue State, Nigeria, using electrical resistivity method. J. Earth Syst. Sci. 1 (24), 124-135.

[21] Mollard, J. D. (1962). Photo-analysis and Interpretation in Engineering geology Investigations. In: Flur, T. and R. F. Legget, eda., Geological Society of America Reviews in Engineering Geol. Vol. 1, pp 105-127.

[22] Knodel, K., Lange, G. and Voigt, H. (2007). Environmental Geology; a handbook of Field Methods and Case Studies, Springer, 1:314 p. 